\title{
Dexamethasone blocks antioestrogen- and oxidant-induced death of pituitary tumour cells
}

\author{
C J Newton, D Bilko, S Pappa and S L Atkin ${ }^{\mathbf{1}}$
}

Molecular Pharmacology, School of Medicine, Faculty of Health, University of Hull, Hull HU6 7RX, UK

${ }^{1}$ Diabetes and Endocrinology, School of Medicine, Faculty of Health, University of Hull, Hull HU6 7RX, UK

(Requests for offprints should be addressed to C J Newton, Medical Research Laboratory, Wolfson Building, University of Hull, Cottingham Road, Hull HU6 7RX, UK; Email: C.J.Newton@medschool.hull.ac.uk)

\begin{abstract}
The oestrogen receptor is fundamental to the growth and survival of the rat pituitary tumour cell line, $\mathrm{GH}_{3}$. Our previous studies have shown that antioestrogens such as RU 58668 and ZM 182780 will reduce the rate of cell division and also induce cell death. Death of these cells in response to antioestrogen treatment appears to be due to a heightened sensitivity to reactive oxygen species (ROS). As part of a study to determine the cross-talk between steroid receptor systems in these cells, we have observed that the glucocorticoid, dexamethasone (Dex), inhibits antioestrogen-induced cell death. Cell death induced by $\mathrm{H}_{2} \mathrm{O}_{2}$ is enhanced by $\mathrm{ZM} 182780$ and this effect is also blocked by Dex. As apoptotic cell death in a number of systems involves an early loss of mitochondrial membrane potential $\left(\Delta \Psi_{\mathrm{m}}\right)$, we have performed detailed studies on the time-course of $\Delta \Psi_{\mathrm{m}}$ loss in relation to the loss in cell membrane function. These studies have indicated that a loss of $\Delta \Psi_{\mathrm{m}}$ parallels a loss of cell membrane function this is more characteristic of necrosis than of apoptosis.
\end{abstract}

From microscopic observations of these cells in response to $\mathrm{H}_{2} \mathrm{O}_{2}$, it has been noted that early cell membrane blebbing, induced by $\mathrm{H}_{2} \mathrm{O}_{2}$, is blocked in the presence of $\mathrm{ZM}$ 182780. Cell membrane blebbing can precede necrosis as well as apoptosis and it is thought to involve cytoskeletal changes, for which localised glycolytic reactions provide ATP. These observations, together with those showing that removal of glucose, but not inhibition of mitochondrial function, enhances ROS-induced cell death, prompted studies on the glycolytic pathway. As a strong candidate mechanism, it would appear that, via an effect on one of the rate-limiting glycolytic enzymes, glyceraldehyde-3-phosphate dehydrogenase, Dex is able to overcome the antioestrogen-enhanced loss of glycolytic function following exposure of cells to ROS. This report contributes to the growing body of evidence showing that glucocorticoids provide a survival advantage to both normal and tumour cell types.

Journal of Endocrinology (2001) 169, 249-261

\section{Introduction}

A characteristic response of tumour cell types that contain the oestrogen receptor (ER) is that oestrogens induce growth (Katzenellenbogen et al. 1979). There are exceptions to this rule, however. Although a considerable amount of evidence has accumulated that prolactinsecreting human pituitary tumours contain the ER (Friend et al. 1994), there is little strong evidence to indicate that these tumours are oestrogen-induced or even oestrogen dependent for growth. In contrast, this is not the case for the rat. Several strains of rat develop oestrogen-induced prolactin-secreting tumours (Wiklund et al. 1981). An ER-containing rat pituitary cell often used for studies on the effect of estrogens is the $\mathrm{GH}_{3}$ cell line (Tashjian et al. 1968). Although these cells were not originally obtained from an oestrogen-induced tumour, both growth and prolactin secretion are suppressed by the addition of antioestrogens to cells in culture (Newton et al. 1994a). Despite these observations with antioestrogens, a peculiarity of these cells is that growth is not always responsive to oestrogens (Haug \& Gautvik 1976, Sorrentino et al. 1976). A few years ago this problem was solved by studies using the pure antioestrogen, ZM 182780, where it was shown that the ER within these cells functions as a transcription factor in the absence of oestrogens (Newton et al. 1994b). It was apparent from these studies that the receptor could be made transcriptionally active by estrogens and also in response to signalling pathways activated by the growth factors, insulin, insulin-like growth factor-I (Newton et al. 1994c) and the cytokine, interleukin-2 (Newton et al. 1994a).

More recent work with this cell line has demonstrated that extended culture in the presence of the pure steroidal antioestrogen, ZM 182780, induces cell death, an effect that is fully reversed by oestrogens (Newton 1995). The 
mechanism for this has been partially elucidated by studies showing that cell death is due to the accumulation of reactive oxygen species (ROS), and that sensitivity to these agents is enhanced by antioestrogen-induced loss of ER function (Newton et al. 1999). A major conclusion from these studies was that functional ablation of the ER sensitises cells to ROS-induced metabolic collapse, leading to cell death with some of the characteristics of apoptosis (Schwartzman \& Cidlowski 1993).

In addition to the ER, the other members of the superfamily of nuclear receptors (Hurd \& Moudgil 1998) known to exist within the $\mathrm{GH}_{3}$ cells are the progesterone receptor (Newton et al. 1994a), the glucocorticoid receptor (Perrone et al. 1980), the thyroid hormone receptor and the retinoic acid receptors (Morita et al. 1990). Studies over the past decade have demonstrated marked functional crosstalk between receptor systems (Bunone et al. 1996). In this respect, tri-iodothyronine $\left(\mathrm{T}_{3}\right)$-induced growth of $\mathrm{GH}_{3}$ cells has been shown to be inhibited by antioestrogens (Zhou-Li et al. 1992). Similarly, the synthetic glucocorticoid, dexamethasone (Dex), has been shown to inhibit both oestrogen- and $\mathrm{T}_{3}$-induced growth of $\mathrm{GH}_{3}$ cells (Zhou-Li et al. 1991). Indeed, it would appear that Dex is able to reduce oestrogen-induced growth in other systems (Bigsby \& Young 1993). During our experiments on the functional cross-talk between nuclear receptor systems in $\mathrm{GH}_{3}$ cells, one of the combinations tested was Dex and the pure antioestrogen, ZM 182780 (Wakeling \& Bowler 1991). Cell death induced by exposure to antioestrogen for several days was completely blocked by Dex. In the current report, we have determined whether this response was specific for the interaction of Dex with the glucocorticoid receptor or whether it is shared by other steroid hormones. Based on our previous observations, outlined above, we have also tested whether Dex blocks cell death due to ROS generated as the result of the addition of the prooxidant, $\mathrm{H}_{2} \mathrm{O}_{2}$. Finally, by modulating glycolytic function, we have determined the role that the cellular bioenergetics status plays in the response of these cells to both the antioestrogen and to the glucocorticoid, Dex.

\section{Materials and Methods}

\section{Reagents}

All reagents for cell culture were obtained from Life Technologies (Paisley, Strathclyde, UK). The cell death ELISA was obtained from Roche Diagnostics Ltd (Lewes, E Sussex, UK). Fluorescent probes for flow cytometry were obtained from Molecular Probes (Cambridge Bioscience, Cambridge, Cambs, UK). Other flow cytometry reagents were obtained from Beckton Dickinson UK Ltd, Oxford, UK. All other reagents were obtained from Sigma-Aldrich Co. Ltd (Poole, Dorset, UK). The pure antioestrogen was obtained as a gift from Zeneca Pharmaceutucals Ltd (Macclesfield, Cheshire, UK).

\section{Cell culture}

Pituitary $\mathrm{GH}_{3}$ cells as previously described (Newton et al. 1994b) were maintained in Dulbecco's modified Eagle's medium (DMEM) with phenol red, penicillin $(50 \mathrm{U} / \mathrm{ml})$ streptomycin $(50 \mu \mathrm{g} / \mathrm{ml})$, amphoteracin $(2 \mu \mathrm{g} / \mathrm{ml})$ and $10 \%$ foetal calf serum (Myoclone; Gibco, Paisley, Strathclyde, UK). For the majority of studies reported here, experiments were conducted on cells seeded onto 48-well culture plates at densities over the range 4000 to 10000 cells per $\mathrm{cm}^{2}$. Cells were kept at $37^{\circ} \mathrm{C}$ in an atmosphere of $5 \% \mathrm{CO}_{2}$ in air. For flow cytometry and enzyme measurements, cells were harvested from $75 \mathrm{~cm}^{2}$ culture flasks by the addition of trypsin/EDTA and resuspended in culture medium. For flow cytometry, cells were treated in suspension at $37^{\circ} \mathrm{C}$ in a gas atmosphere of $5 \% \mathrm{CO}_{2}$ in air.

\section{Transfection}

Plasmids for transfection were the MMTV-Luc and $\triangle$ MTV-Luc as previously described (Newton et al. 1994c). After seeding and cell attachment, media were changed to phenol red-free DMEM containing 10\% charcoal-stripped serum and $24 \mathrm{~h}$ later transfections were made with $1 \mu \mathrm{g}$ plasmid DNA and the reagent FUGENE, according to the manufacturer's instructions (Roche Diagnostics Ltd). After a further $24 \mathrm{~h}$, luciferase activity was measured in the cell lysates using the Promega luciferase assay system (Madison, WI, USA). All values obtained as relative light units, measured with a luminometer, were expressed as fold control (no treatment).

\section{Determination of cell numbers and cell death}

We have previously shown that viable cell numbers can be quantitated by the addition of the diazo dye 3-[4,5dimethylthiazol-2-yl]-2,5-diphenyltetrazdium bromide (MTT) to cells for $4 \mathrm{~h}$ to give final concentration of $0 \cdot 1 \mathrm{mg} / \mathrm{ml}$ (Newton 1995). The blue crystals formed were solubilised by the addition of sodium dodecylsulphate in $\mathrm{HCl}$ to give final concentrations of $10 \%$ and $10 \mathrm{mM}$ respectively. Absorbance values were determined at $550 \mathrm{~nm}$. For the experiment shown in Fig. 3, a direct estimate of cell numbers was made using a Coulter Counter (Beckman Coulter Ltd, High Wycombe, UK). Prior to assay, cell monolayers were washed twice with phosphate-buffered saline (PBS) to remove poorly attaching, dead cells.

As described previously (Newton et al. 1999), a quantitative measure of cell death was made by determining DNA fragmentation using the ELISA ${ }^{\text {PLUS }}$ assay (Roche Diagnostics Ltd).

\section{Fluorescence microscopy}

Normal light (Image Modulated Contrast) and fluorescence microscopy were performed with a Leica DMIL 
fitted with a SPOT ${ }^{\mathrm{JUNIOR}}$ digital camera (Diagnostic Instruments, Oxnard, CA, USA). Photo-quality pictures were produced with a Hewlett Packard 970 Cxi. To determine the integrity of cell membranes, a mixture of propidium iodide (PI) and Hoechst 33342 was added to the cell culture medium to give final concentrations of $10 \mu \mathrm{g} / \mathrm{ml}$ and $1 \mu \mathrm{g} / \mathrm{ml}$ respectively. After $5 \mathrm{~min}$ at $37^{\circ} \mathrm{C}$, cells were visualised following exposure to normal and UV light $(380 \mathrm{~nm})$. Cells with disrupted membranes preferentially gave red nuclear fluorescence due to the uptake of PI. Cells with intact membranes gave blue nuclear fluorescence, due to the uptake of the cell-permeable Hoechst 33342 fluorochrome.

Flow cytometry for changes in mitochondrial membrane potential

Mitochondrial membrane potential $\left(\Delta \Psi_{\mathrm{m}}\right)$ was determined by a previously published method (Decaudin et al. 1997). Control and steroid pretreated (24 h) cells were harvested from $75 \mathrm{~cm}^{2}$ flasks by the addition of trypsin/ EDTA and exposed, in suspension, to $150 \mu \mathrm{M} \mathrm{H} \mathrm{H}_{2} \mathrm{O}_{2}$. After $1 \mathrm{~h}$ and thereafter at approximately 30-min intervals, $300 \mu \mathrm{l}$ cell suspension was taken to which was added $30 \mu \mathrm{l}$ PBS containing the cationic dye, 3,3'dihexyloxacarbocyanine iodide $\left(\mathrm{DiOC}_{6}\right)$ (Molecular Probes; final concentration $80 \mu \mathrm{M})$, and PI $(1 \mu \mathrm{g} / \mathrm{ml})$. Labelled cells were then incubated for $10 \mathrm{~min}$ at $37^{\circ} \mathrm{C}$ prior to sampling with a FACS ${ }^{\text {Calibur }}$ flow cytometer (Becton Dickinson UK Ltd) using an argon laser tuned to $480 \mathrm{~nm}$. Fluorescence emissions were detected in green and red channels and plotted on the $\mathrm{x}$ axis against the number of cell on the y axis. Loss of $\Delta \Psi_{\mathrm{m}}$ was detected as a decrease in green fluorescence intensity. Loss of membrane integrity was observed by an increase in the red fluorescence.

In addition to the flow cytometry method, the $\Delta \Psi_{\mathrm{m}}$ was also determined by fluorescence microscopy using the cationic dye, 5,5',6,6'-tetrachloro-1,1,3,3'-tetraethylbenzimidolycarbocyanine iodide (JC-1) and exposure to light at $480 \mathrm{~nm}$. As a cation, this dye is taken-up by mitochondria according to the membrane potential (Coulter et al. 2000). At low potential, the dye exists as a monomer and fluoresces green. At high potential, JC-1 forms ' $\mathrm{J}$ ' aggregates and fluoresces red.

\section{Cellular ATP concentrations and glyceraldehyde-3-phosphate dehydrogenase activity}

ATP was determined in cell lysates with a luminescent assay. Medium was removed from treated cells in 48-well plates and $0.5 \mathrm{ml}$ distilled water was added. After a period of 1-2 min the cell lysate was aspirated and boiled for $5 \mathrm{~min}$. This was then diluted with a further $1 \mathrm{ml}$ distilled water and $100 \mu \mathrm{l}$ aliquots were mixed with a $100 \mu \mathrm{l}$ aliquot of a luciferase/luciferin mixture provided by Sigma-
Aldrich Co. (FL-AA). Values were recorded as relative light units and are expressed as a percentage of those obtained for untreated control cells. Values obtained from the experiments fell within the wide linear range of the assay.

Glyceraldehyde-3-phosphate dehydrogenase (GAPDH) activity was determined as described by Halder et al. (1993). In brief, cells harvested from $75 \mathrm{~cm}^{2}$ flasks were sonicated on ice in PBS to break cytosolic membranes. The sonicate was then centrifuged at $1500 \mathrm{~g}$ and an aliquot of the crude cytosol containing supernatant was taken for spectrophotometric GAPDH assay according to the methodology described by Scheek \& Slater (1982). Values obtained for enzyme activity in $\mu \mathrm{mol} \mathrm{NADH}$ produced/min were corrected for protein content and then expressed as percentage of those obtained for untreated, control cells.

\section{Statistics}

Where indicated, statistical analysis was performed on a minimum of three replicates using the Student's $t$-test. With the exception of Fig. 5, figures are reproduced as representative experiments from at least five identical studies. All values given in the figures are expressed as means \pm s.D. For clarity, error bars have been omitted from some figures.

\section{Results}

Functional activation of steroid receptors and effect of ligands on ZM 182780-induced cell death

To determine the functional activity of the steroid receptors present in $\mathrm{GH}_{3}$ cells, transfection was performed with the MMTV-Luc and $\triangle$ MTV-ERE-Luc reporter plasmids (Newton et al. 1994b) followed by a 24-h treatment period with the progestin, promogestone (R5020, $10 \mathrm{nM}$ ), the androgen, dihydrotestosterone (DHT, $10 \mathrm{nM}$ ), the glucocorticoid, Dex $(100 \mathrm{nM})$ and the oestrogen, oestradiol $\left(\mathrm{E}_{2}\right.$, $1 \mathrm{nM})$. To ensure the removal of endogenous steroids, cells were maintained prior to treatment in phenol redfree medium containing charcoal-stripped serum. Figure 1 shows that all steroids induced reporter gene expression and that the respective receptor antagonists, ZK 98299 (progesterone receptor (PR), $10 \mu \mathrm{M}$ ), RU 486 (glucocorticoid receptor (GR), $10 \mu \mathrm{M}$ ), hydroxyflutamide (androgen receptor (AR), $10 \mu \mathrm{M}$ ) and ZM 182780 (ER, $100 \mathrm{nM}$ ) blocked transcription of the reporter genes. It should be noted that for transfections peformed with the $\triangle$ MTV-ERE-Luc plasmid, the antioestrogen reduced luciferase expression below that of the oestrogen-free control. This is consistent with earlier studies showing that the ER within these cells is transcriptionally active in the absence of oestrogen (Newton et al. 1994c).

To determine whether the ligand-activated receptors altered the response of cells to the antioestrogen, cultures 

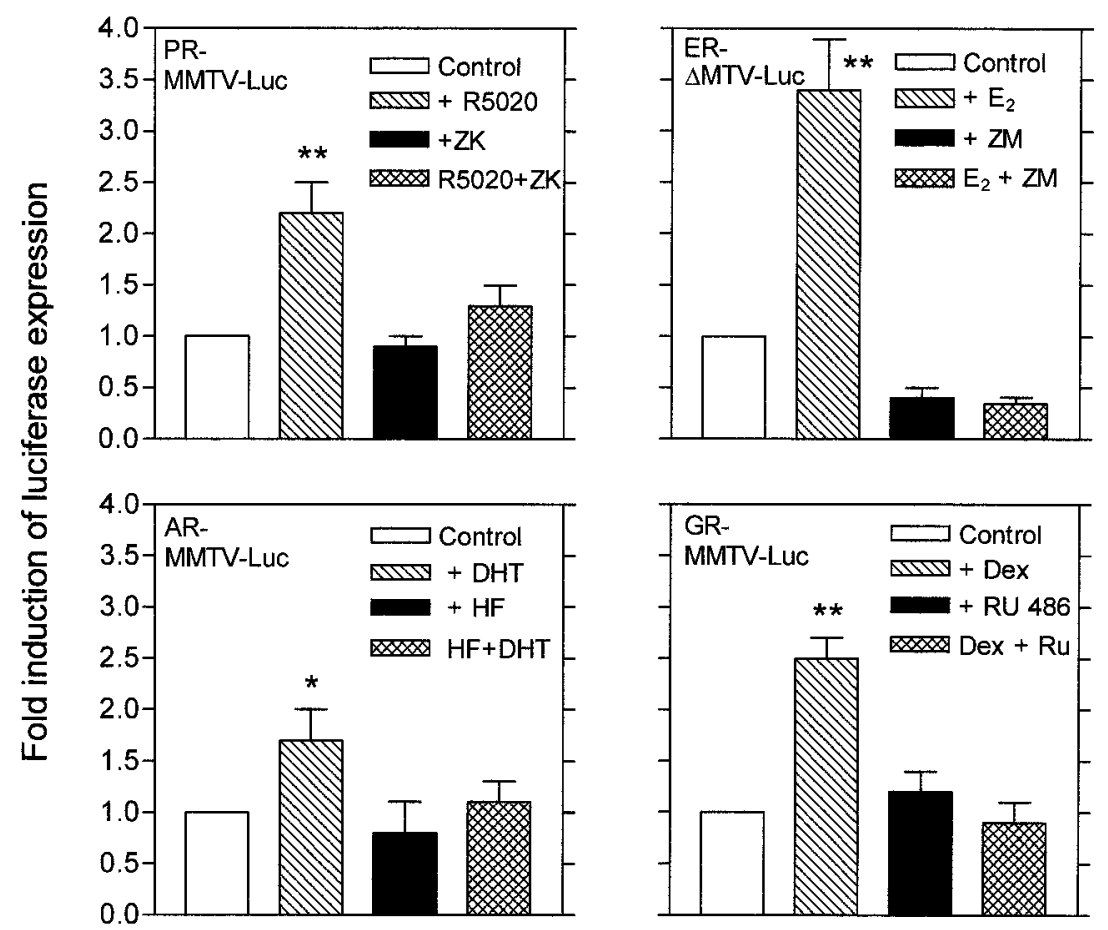

Figure 1 Steroid receptor activation in $\mathrm{GH}_{3}$ cells. Cells were transfected with $1 \mu \mathrm{g}$ MMTV-Luc or $\triangle$ MTV-ERE-Luc plasmids and then exposed to steroids in the absence and presence of specific receptor antagonists. Luciferase activity detected $24 \mathrm{~h}$ after transfection is expressed as a function of that detected in transfected but otherwise untreated cells. Steroid/steroid antagonist concentrations: R5020, 10 nM; ZK 98299 (ZK), $10 \mu \mathrm{M}$; $\mathrm{E}_{2}, 1 \mathrm{nM}$; ZM 182780 (ZM), $100 \mathrm{nM}$; DHT, $10 \mathrm{nM}$; hydroxyflutamide (HF), $10 \mu \mathrm{M}$; Dex, $100 \mathrm{nM}$; RU $486(\mathrm{Ru}), 10 \mu \mathrm{M}$. Error bars in this and other figures are means \pm S.D. ${ }^{*} P<0 \cdot 01,{ }^{* *} P<0 \cdot 001$ versus control.

were maintained in the presence of $100 \mathrm{nM}$ ZM 182780 and a dose range of Dex, R5020, DHT, oestrone $\left(\mathrm{E}_{1}\right)$ and $\mathrm{E}_{2}$. Figure 2 demonstrates the response of $\mathrm{GH}_{3}$ cells measured as metabolic activity by the addition of the redox sensitive diazo dye, MTT. In comparison to $\mathrm{E}_{1}$ and $\mathrm{E}_{2}$, where metabolic activity was restored to that of cells untreated with antioestrogen, only Dex was observed to partially reverse the antioestrogen-induced decrease of metabolic activity. For estimates of the proportion of viable cells, determined by the addition of the fluorochromes, Hoechst 33342 and PI, Fig. 2b shows that Dex completely blocked the antioestrogen-induced loss of cell viability. It should be mentioned that unlike $\mathrm{E}_{2}, \mathrm{E}_{1}$ was able to maintain cell viability at concentrations 100 -fold lower than for $E_{2}$. As $E_{1}$ has a lower affinity for the ER than $E_{2}$, this suggests that either the effect of $E_{1}$ is mediated via an ER isoform to which the antioestrogen fails to bind, or that the effect of $E_{1}$ is mediated via an ER-independent pathway.

To provide confirmation of the effect of Dex, a further experiment was performed over a time-course of 9 days, where cell numbers were measured using a Coulter Counter. Figure 3 shows that in the presence of $\mathrm{ZM}$
182780 alone, cell numbers fell by day 5, but growth continued at a low rate in the combined presence of $100 \mathrm{nM}$ ZM 182780 and $100 \mathrm{nM}$ Dex.

Antioestrogen- and exogenous oxidant-induced cell death is blocked by Dex

We have previously shown that death induced by ZM 182780 results in extensive DNA fragmentation (Newton et al. 1999). Using the same ELISA method, we determined the effect of Dex on the time-course of antioestrogen-induced DNA fragmentation. Figure $4 \mathrm{a}$ shows that over a time-course of 7 days, DNA fragmentation began to rise from day 4 and this was completely blocked by $100 \mathrm{nM}$ Dex. Given that we have previously shown that oxidants are involved in antioestrogen-induced death of $\mathrm{GH}_{3}$ cells, we next tested the response of cells to the pro-oxidant, $\mathrm{H}_{2} \mathrm{O}_{2}$. Previously untreated control cells and cells exposed to $100 \mathrm{nM} \mathrm{ZM} 182780$ for $48 \mathrm{~h}$ were treated with a dose range of $\mathrm{H}_{2} \mathrm{O}_{2}$ for $2 \mathrm{~h}$. At concentrations of $\mathrm{H}_{2} \mathrm{O}_{2}$ around $100-200 \mu \mathrm{M}$, DNA fragmentation was markedly enhanced for antioestrogenexposed cells (Fig. 4b). As indicated previously (Newton 
(a)

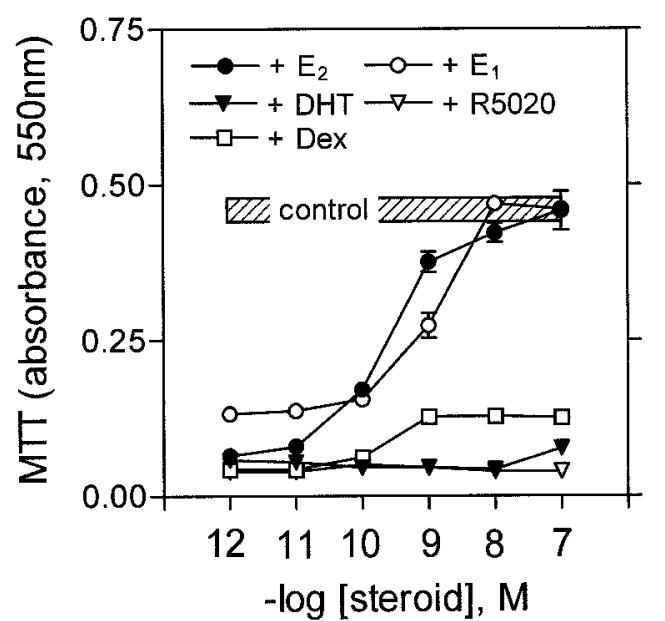

(b)

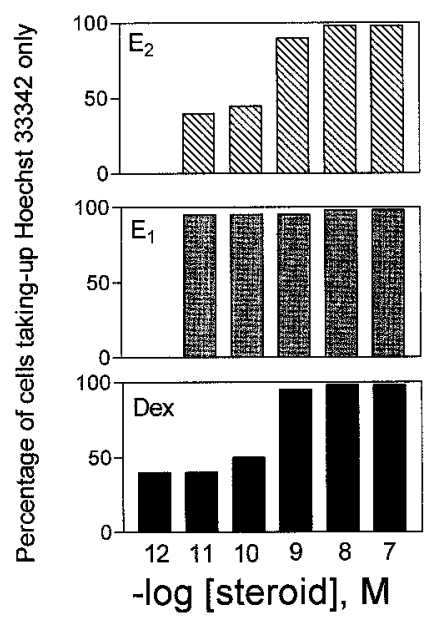

Figure 2 Response of antioestrogen-treated cells to a dose range of steroids measured in (a) as metabolic activity after 5 days of treatment and in $(b)$ as the proportion of viable cells. Apart from metabolic activity of control cells, represented as the hatched bar (means \pm S.D.) in (a), all other cells received 100 nM ZM 182780 along with the steroids at the concentrations indicated.

et al. 1999), over a time-period of $1-2 \mathrm{~h}, \mathrm{GH}_{3}$ cells paradoxically fail to show DNA fragmentation at the higher pro-oxidant doses. Figure $4 \mathrm{~b}$ also shows that pretreatment of cells with $100 \mathrm{nM}$ Dex in the absence or presence of ZM 182780 markedly blocked DNA fragmentation induced by the low doses of $\mathrm{H}_{2} \mathrm{O}_{2}$.

\section{Characteristics of oxidant-induced death}

As loss of $\Delta \Psi_{\mathrm{m}}$ is one of the earliest events in apoptosis, the effect of $\mathrm{H}_{2} \mathrm{O}_{2}$ in combination with ZM 182780 alone, with Dex and with the antiglucocorticoid, RU 486 was

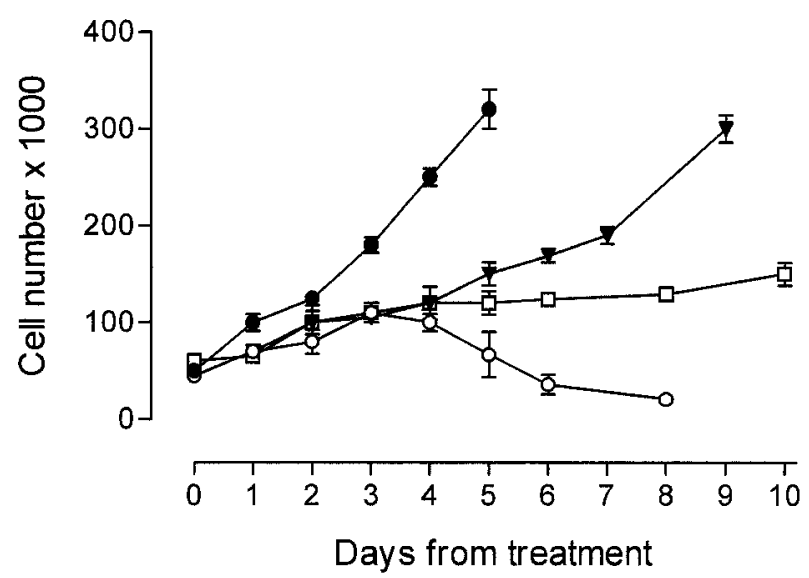

Figure 3 Growth curves for cells treated with ZM 182780 $(100 \mathrm{nM})$ alone $(\bigcirc)$, for cells treated with Dex $(100 \mathrm{nM})$ alone $(\boldsymbol{\nabla})$, and for ZM 182780 and Dex $(\square)$, over an extended time-course of 10 days. Control ( determined as a function of time after treatment. Cells pretreated for $48 \mathrm{~h}$ with ZM $182780(100 \mathrm{nM})$ alone or in combination with Dex $(100 \mathrm{nM})$ and RU $486(10 \mu \mathrm{M})$ were exposed to $150 \mu \mathrm{M} \mathrm{H}_{2} \mathrm{O}_{2}$ for various times over a 4to 5-h period, prior to the addition of a mixture of the $\Delta \Psi_{\mathrm{m}}$-sensitive fluorochrome, $\mathrm{DiOC}_{6}$, and the marker for membrane integrity, PI, as described in Materials and Methods. For all experiments conducted $(n=3)$, it was observed that after 90-min exposure to $\mathrm{H}_{2} \mathrm{O}_{2}$ the $\Delta \Psi_{\mathrm{m}}$ decreased for cells pre-exposed to ZM 182780 and this was paralleled by the uptake of PI. Figure 5 shows the results from one experiment typical of all three. It is clear

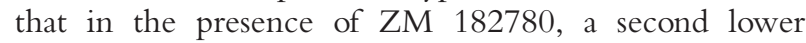
intensity peak was observed for $\mathrm{DiOC}_{6}$ and this correlated with a large uptake of PI as indicated by the adjacent profiles. Both the lower intensity fluorescence peak, corresponding to cells with a low $\Delta \Psi_{\mathrm{m}}$, and the high intensity red fluorescence peak, indicating PI uptake, were markedly attenuated by Dex; a response reversed by RU 486 . It should be noted that, in this experiment, no marked effect on $\Delta \Psi_{\mathrm{m}}$ and PI uptake could be observed when $\mathrm{H}_{2} \mathrm{O}_{2}$ was added alone to cells (control). Although only the 90-min exposure time is shown in Fig. 5, for all experiments conducted, Dex was still able to significantly reduce $\mathrm{H}_{2} \mathrm{O}_{2}$-induced $\mathrm{PI}$ uptake after exposure to $\mathrm{H}_{2} \mathrm{O}_{2}$ for $4 \mathrm{~h}\left(\mathrm{ZM} 182780+\mathrm{H}_{2} \mathrm{O}_{2}\right.$ vs ZM 182780+Dex $+\mathrm{H}_{2} \mathrm{O}_{2}$; $67 \pm 12 \%$ vs $26 \pm 8 \%, P<0 \cdot 01$; paired $t$-test at $90 \mathrm{~min}, 1$, 2,3 and $4 \mathrm{~h}$ for data from three experiments).

For all three experiments, the percentage of the cell population with a low $\Delta \Psi_{\mathrm{m}}$ was correlated with the proportion of the cell population showing PI uptake, for the 90 min, 2, 3 and $4 \mathrm{~h}$ sampling times (Fig. 6). Statistical 
(a)

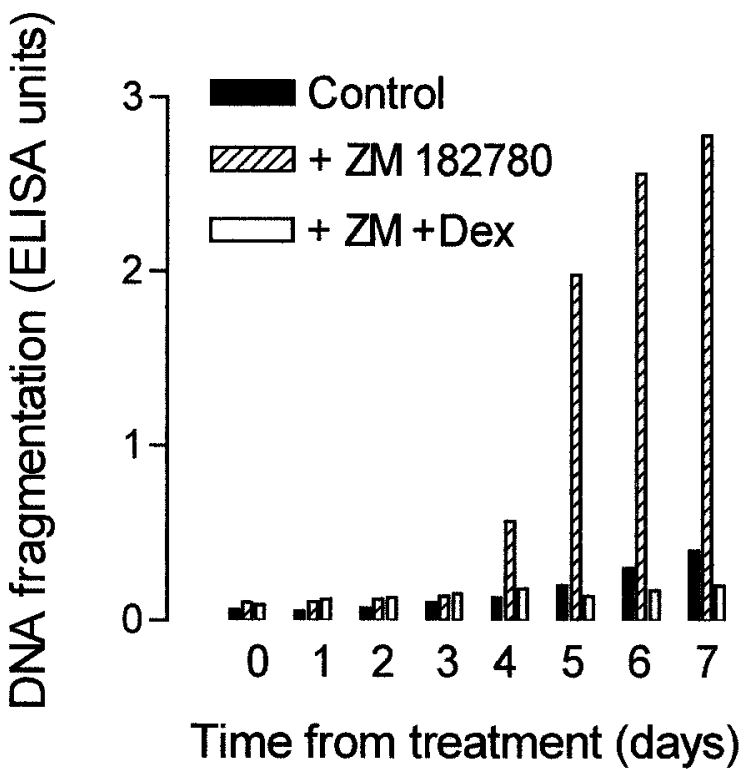

(b)

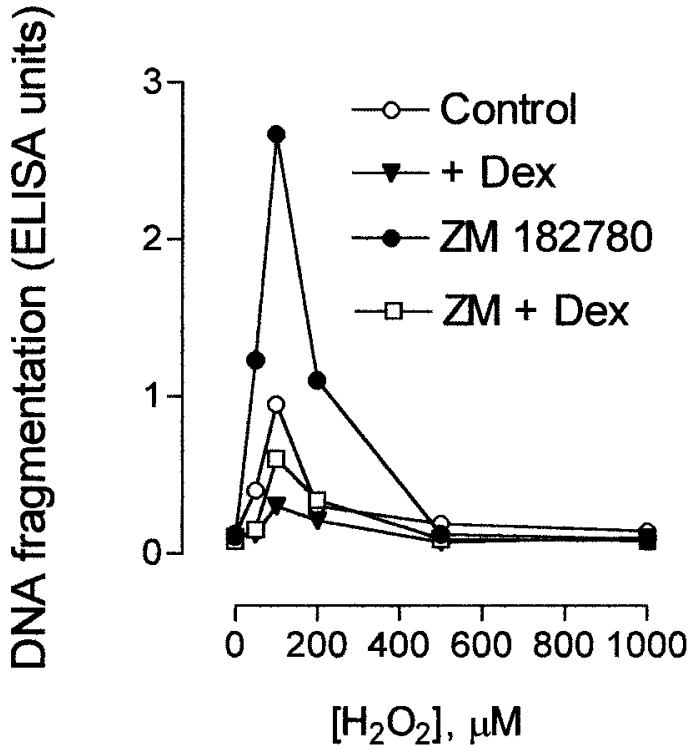

Figure 4 The ability of the glucocorticoid, Dex, to block antioestrogen-induced and exogenous oxidant-induced cell death. In (a) the time-course for the response to ZM $182780(\mathrm{ZM} ; 100 \mathrm{nM})$ and Dex $(100 \mathrm{nM})$ is presented, whilst in (b) the dose-response to a 2-h exposure to $\mathrm{H}_{2} \mathrm{O}_{2}$ in the presence of $\mathrm{ZM} 182780$ (100 nM), and/or Dex (100 nM) is shown.

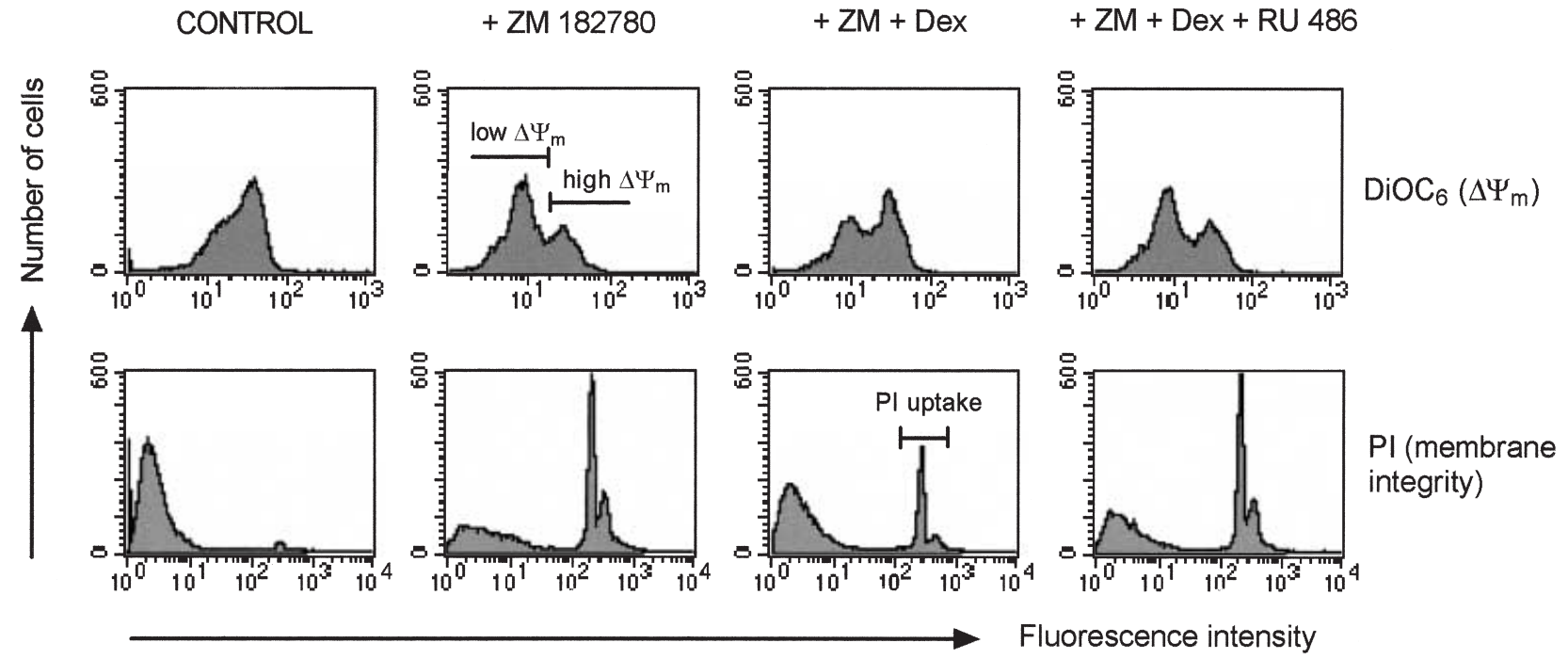

Figure $5 \Delta \Psi_{m}$ and cell membrane integrity in response to 90-min exposure to $\mathrm{H}_{2} \mathrm{O}_{2}$ following pre-treatment (48 h) of cells with ZM 182780 (ZM; $100 \mathrm{nM}$ ), or with ZM 182780 and Dex (100 nM) or ZM 182780, Dex and the antiglucocorticoid, RU 486 (10 $\mu$ M). The top row of histograms show green fluorescence intensity $\left(\Delta \Psi_{m}\right)$ for cells stained with the mitochondrial fluorochrome, DiOC 6 . The corresponding panels below show the uptake of $\mathrm{PI}$ (membrane integrity). Cells with a loss of $\Delta \Psi_{\mathrm{m}}$ are those giving the second low intensity fluorescence peak, whilst loss of membrane integrity is apparent by the appearance of peaks at high red fluorescence.

analysis reveals a correlation coefficient of 0.914 and a slope of $1 \cdot 07$. This analysis shows that at no time-point following $\mathrm{H}_{2} \mathrm{O}_{2}$ exposure, could the loss of the $\Delta \Psi_{\mathrm{m}}$ be disassociated from the uptake of PI.
A further possibility that might explain the above findings is that membrane integrity is lost following a catastrophic loss of mitochondrial function. To address this, $\mathrm{GH}_{3}$ cells were stained with the mitochondrial 


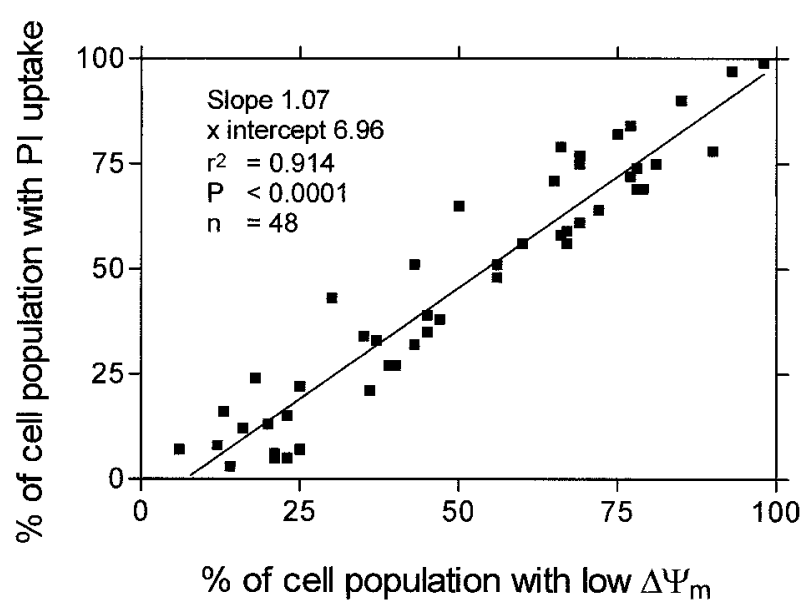

Figure 6 Correlation between the percentage of the cell population with a low $\Delta \Psi_{\mathrm{m}}$ and the percentage that have taken-up PI following treatment with $\mathrm{H}_{2} \mathrm{O}_{2}(150 \mu \mathrm{M})$ in combination with ZM $182780(100 \mathrm{nM})$, Dex (100 nM) and RU $486(10 \mu \mathrm{M})$. Values shown were obtained after $90 \mathrm{~min}, 2 \mathrm{~h}, 3 \mathrm{~h}$ and $4 \mathrm{~h}$ exposure to $\mathrm{H}_{2} \mathrm{O}_{2}$ and were from three different experiments.

fluorchrome, JC-1. Like $\mathrm{DiOC}_{6}$, this cationic compound accumulates in mitochondria but, unlike $\mathrm{DiOC}_{6}$, it has the further property that at high $\Delta \Psi_{\mathrm{m}}$, it forms red fluorescent 'J' aggregates. Figure $7 \mathrm{a}$ shows cells treated with JC-1 alone for $30 \mathrm{~min}$ (positive control for $\Delta \Psi_{\mathrm{m}}$ ) in comparison with cells treated with $\mathrm{JC}-1$ and the protonophore, $\mathrm{mClCCP}(100 \mu \mathrm{M}$; Fig. $7 \mathrm{~b})$ where orange/red fluorescence is absent (negative control for $\Delta \Psi_{\mathrm{m}}$ ). Figure $7 \mathrm{c}-\mathrm{h}$ shows the results of another experiment where in comparison with the control for the addition of JC-1 (Fig. 7c) and Hoechst 33342 alone (Fig. 7d), around $50 \%$ of cells have a low $\Delta \Psi_{\mathrm{m}}$ (Fig. 7e) and a similar proportion have lost membrane integrity (Fig. 7f), as indicated by the nuclear uptake of PI (red nuclei), when treated for 90 min with $150 \mu \mathrm{M} \mathrm{H}_{2} \mathrm{O}_{2}$. In contrast, whilst all cells treated with $1 \mathrm{mM} \mathrm{H}_{2} \mathrm{O}_{2}$ for $90 \mathrm{~min}$ have a low $\Delta \Psi_{\mathrm{m}}$ (Fig. $7 \mathrm{~g}$ ), none of these cells show PI uptake (Fig. $7 \mathrm{~h}$ ). Although not shown, these cells treated with the high dose of $\mathrm{H}_{2} \mathrm{O}_{2}$ continued to exclude PI for 4-5 h. These data strongly suggest that loss of $\Delta \Psi_{\mathrm{m}}$ is due to a catastrophic loss of cell membrane integrity and not vice versa.

\section{Mechanism for Dex blockade of antioestrogen- and oxidant-induced death}

Cellular ATP concentrations in response to $\mathrm{H}_{2} \mathrm{O}_{2}$ Cell death involving a loss of membrane integrity is often associated with insufficient cellular ATP to maintain plasma membrane $\mathrm{Na}^{+} / \mathrm{K}^{+}$-ATPase activity. Experiments were conducted to determine the ATP status of cells in relation to the time at which PI uptake occurred following challenge with $\mathrm{H}_{2} \mathrm{O}_{2}$. Figure 8a shows that after 30-min exposure of cells to $1 \mathrm{mM} \mathrm{H}_{2} \mathrm{O}_{2}$, ATP concentrations had fallen to $10 \%$ of control values. At this time-point, Fig. $8 \mathrm{~b}$ shows that PI uptake had not occurred. After a further 30 min, Fig. 8a shows that at the low pro-oxidant concentration of $150 \mu \mathrm{M}$, ATP concentrations continued to fall and that this was followed by the uptake of PI, indicating a loss of cell membrane integrity. That ATP levels had fallen so dramatically at the high $\mathrm{H}_{2} \mathrm{O}_{2}$ doses and yet cell death (loss of membrane integrity) failed to occur for several hours, suggested that it was not the absolute cellular ATP concentration that was the factor determining cell survival.

Effect of inhibiting glycolysis and mitochondrial function on response to $\mathrm{H}_{2} \mathrm{O}_{2}$ A further finding was that at the low oxidant doses cells displayed marked membrane blebbing. Figure 9 shows that in comparison with cells treated with a low dose of $\mathrm{H}_{2} \mathrm{O}_{2}$ (Fig. 9b), for high pro-oxidant doses (Fig. 9c), or where cells were pretreated with ZM 182780 (Fig. 9d), membrane blebbing failed to occur. Membrane blebbing is a process of cytoskeletal arrangement and it can precede apoptosis and necrosis (Schwartzman \& Cidlowski 1993). Studies have indicated that glycolytic enzymes are associated with actin and also tubulin cytoskeletal filaments and that glycolysis provides the ATP necessary for the cytoskeletal changes involved in membrane blebbing (Glass-Marmor \& Beitner 1997).

To determine the relative role of glycolytic and mitochondrial ATP generation in the response to $\mathrm{H}_{2} \mathrm{O}_{2}$, cells were incubated in medium lacking glucose or with the protonophore, carbonyl cyanide m-chlorophenylhydrazone (mClCCP) $(100 \mu \mathrm{M}$; Sigma) and the succinate dehydrogenase inhibitor, 3-nitropropionic acid (3NP; $2 \mathrm{mM}$ ). As indicated in Fig. $7 \mathrm{~b}$ the protonophore collapses the $\Delta \Psi_{\mathrm{m}}$ whilst $3 \mathrm{NP}$ will reduce the delivery of electrons to the electron transport chain and lower the $\Delta \Psi_{\mathrm{m}}$ (Keller et al. 1998). Figure 10 shows that the removal of glucose markedly enhanced cell death induced by $\mathrm{H}_{2} \mathrm{O}_{2}$. Surprisingly, both mClCCP and $3 \mathrm{NP}$ gave some degree of protection against the oxidant-induced cell death.

Role of GADPH in the response of cells to antioestrogen and Dex As the experiments above strongly pointed to a fundamental role of glycolysis in the response of these cells to oxidants, experiments were performed to determine the extent to which ZM 182780 and Dex exposure altered GAPDH activity, a rate-limiting enzyme of glycolysis (Sahlin 1995). For cells treated with ZM 182780 and Dex for $48 \mathrm{~h}$, enzyme activity was measured in cell lysates. Table 1 shows that ZM 182780 and Dex treatment alone had no effect on enzyme activity. This experiment was then repeated where cells exposed to $\mathrm{ZM}$ 182780 and Dex for $48 \mathrm{~h}$ were exposed to $150 \mu \mathrm{M} \mathrm{H}_{2} \mathrm{O}_{2}$, 

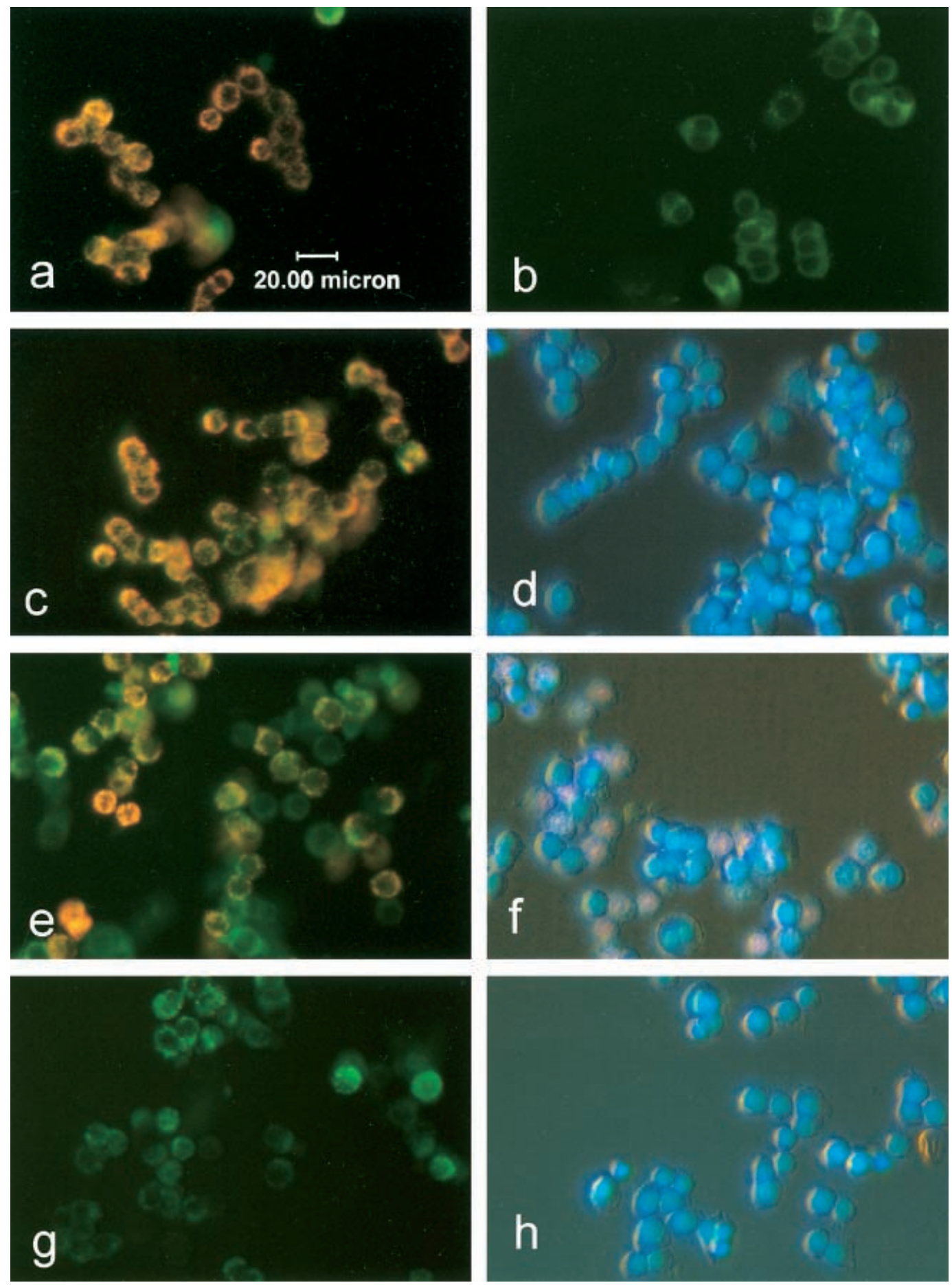

Figure 7 Fluorescence microscopy for $\Delta \Psi_{\mathrm{m}}$ with JC-1 (a, b, c, e, g), and for membrane integrity with Hoechst 33342 and $\mathrm{PI}(\mathrm{d}, \mathrm{f}, \mathrm{h})$. In comparison with cells treated with JC-1 alone (a) where red ' $\mathrm{J}$ ' aggregates are present (high $\Delta \Psi_{\mathrm{m}}$ ) (b) shows only green fluorescence (low $\Delta \Psi_{\mathrm{m}}$ ) in the presence of the protonophore, $\mathrm{mClCCP}$ $(100 \mu \mathrm{M})$. In a separate experiment, $(c-h)$ show the response to treatment with $\mathrm{H}_{2} \mathrm{O}_{2}$ for 90 min. Control cells with JC-1 and Hoechst 33342 are shown in (c) and (d) respectively, whilst (e) and (f) show the effect of low concentrations of $\mathrm{H}_{2} \mathrm{O}_{2}(150 \mu \mathrm{M})$ with JC- 1 and Hoechst 33342 respectively. (The same field for JC-1 and Hoechst 33342 could not be used as JC-1 and Hoechst 33342 gave mutual quenching.) Finally (g) and (h) show the response to the high concentration of $\mathrm{H}_{2} \mathrm{O}_{2}(1 \mathrm{mM})$ with JC-1 and Hoechst 33342 respectively. 
(a)

$$
\begin{aligned}
& \multimap-150 \mu \mathrm{M} \mathrm{H}_{2} \mathrm{O}_{2} \\
& \multimap-1 \mathrm{mM}
\end{aligned}
$$
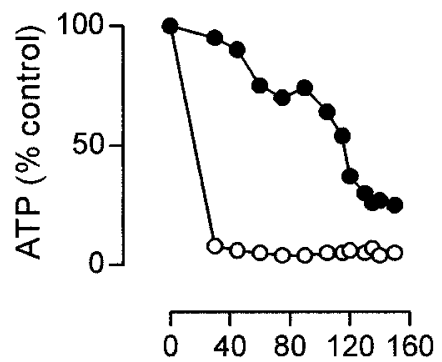

Time from treatment $(\mathrm{min}$.) (b)
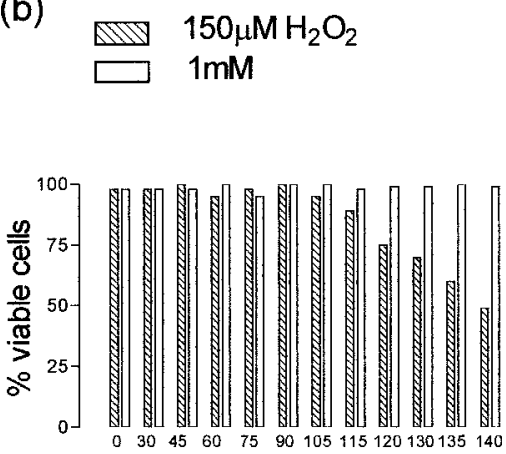

Time from treatment (min.)

Figure 8 ATP concentrations (a) and cell membrane integrity (b) measured at various times after the addition of $\mathrm{H}_{2} \mathrm{O}_{2}(150 \mu \mathrm{M})$. Values are expressed as per cent control.
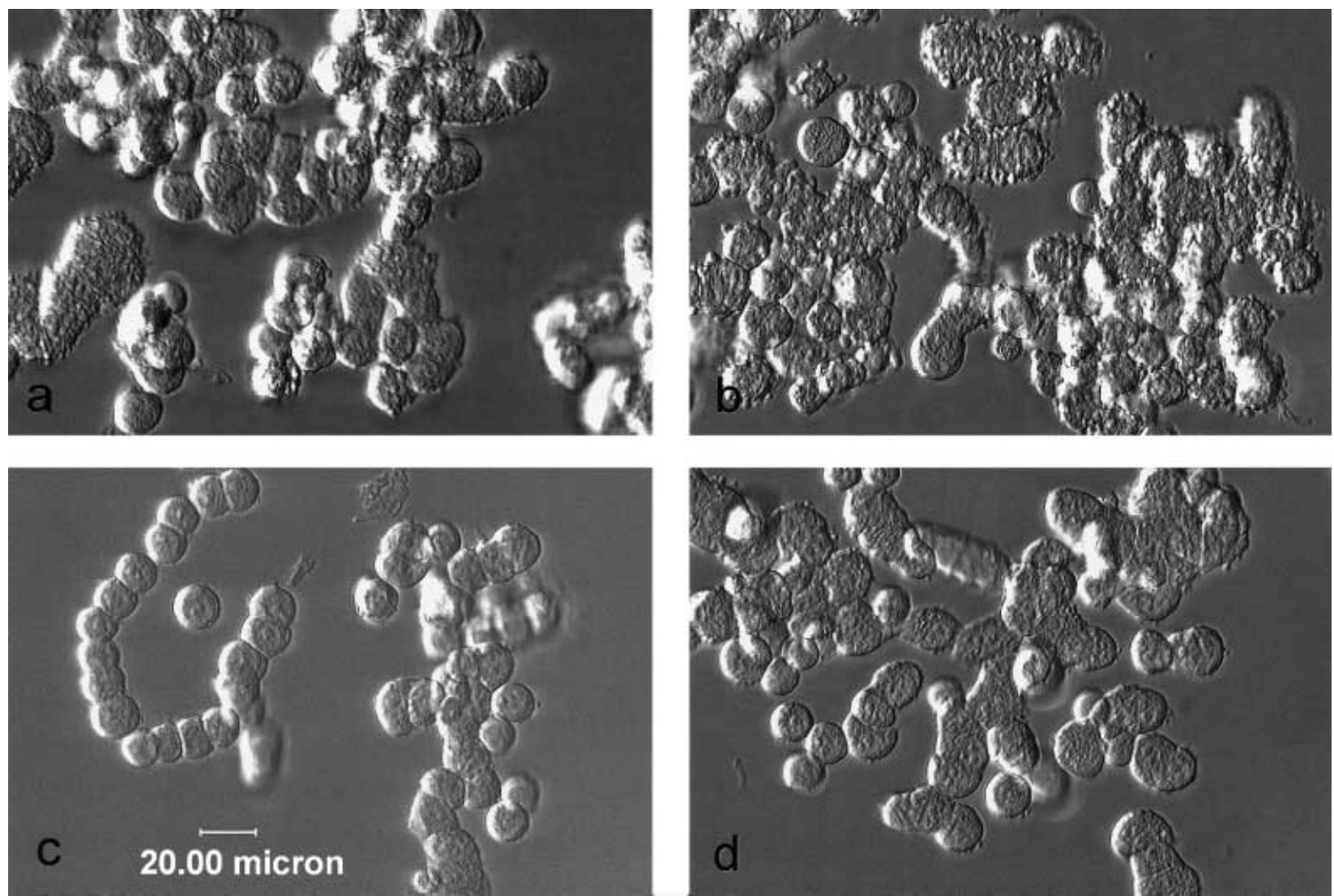

Figure 9 Image Modulated Contrast light microscopy images of $\mathrm{GH}_{3}$ cells showing membrane blebbing on exposure to $150 \mu \mathrm{M} \mathrm{H}_{2} \mathrm{O}_{2}$ for $45 \mathrm{~min}$ (b), in comparison with lack of blebbing for cells treated with $1 \mathrm{mM} \mathrm{H}_{2} \mathrm{O}_{2}$ (c) or for cells treated with $150 \mu \mathrm{M} \mathrm{H}_{2} \mathrm{O}_{2}$, following pre-exposure to ZM 182780 (d). Control, untreated cells are shown in (a).

30 min prior to harvesting for enzyme measurement. As observed in the first experiment, antioestrogen or Dex treatment alone failed to provoke a response but, this time, a fall in enzyme activity occurred for cells exposed to
$\mathrm{H}_{2} \mathrm{O}_{2}$ for $30 \mathrm{~min}$. This decrease of enzyme activity was substantially enhanced in the presence of ZM 182780 and this enhancement was reversed by the inclusion of Dex in the culture medium. 


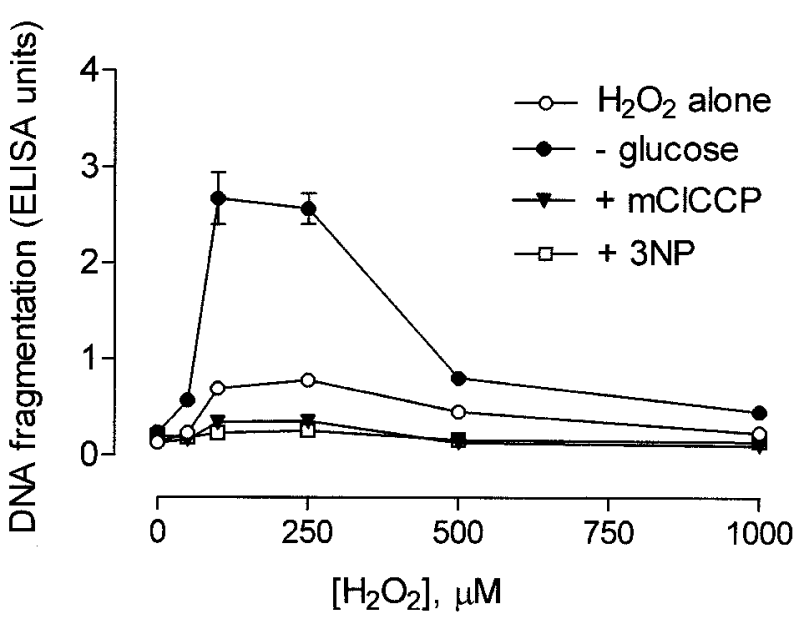

Figure 10 Cell death, as measured by the DNA fragmentation ELISA, in response to $\mathrm{H}_{2} \mathrm{O}_{2}(150 \mu \mathrm{M})$ for cells maintained in the absence of glucose or presence of the protonophore, $\mathrm{mClCCP}$ $(100 \mu \mathrm{M})$ or the succinate dehydrogenase inhibitor, 3NP $(2 \mathrm{mM})$.

Table 1 GAPDH activity detected in $\mathrm{GH}_{3}$ cells exposed to ZM $182780(100 \mathrm{nM})$ and Dex (100 nM) in the absence and presence of $\mathrm{H}_{2} \mathrm{O}_{2}(150 \mu \mathrm{M})$. Values (means \pm S.D.) are given as percentage of control

\begin{tabular}{|c|c|}
\hline & $\begin{array}{l}\text { Enzyme activity } \\
\text { (\% control) }\end{array}$ \\
\hline $\begin{array}{l}\text { Treatment and } \\
\text { experiment } \\
\text { Experiment } 1 \\
\text { Dex } \\
\text { ZM } 182780\end{array}$ & $\begin{array}{l}94 \pm 8 \\
89 \pm 14\end{array}$ \\
\hline $\begin{array}{l}\text { Experiment } 2 \\
\text { Dex } \\
\mathrm{ZM} 182780 \\
\mathrm{H}_{2} \mathrm{O}_{2}(150 \mu \mathrm{M}) \\
\mathrm{H}_{2} \mathrm{O}_{2}+\mathrm{ZM} 182780 \\
\mathrm{H}_{2} \mathrm{O}_{2}+\mathrm{ZM} 182780+\text { Dex }\end{array}$ & $\begin{aligned} 107 & \pm 10 \\
94 & \pm 8 \\
56 & \pm 12^{\mathrm{a}} \\
23 & \pm 8^{\mathrm{b}} \\
64 & \pm 7^{\mathrm{c}}\end{aligned}$ \\
\hline
\end{tabular}

\section{Discussion}

The expansion of a cell mass is dependent on stimuli that activate cell cycle events and those that allow the survival of cell progeny. With regard to the growth and development of rat pituitary tumours, oestrogens are the endocrine agents that would appear to fulfil both these requirements. Therefore, the rat pituitary tumour cells used here are not only dependent on the ER for growth but, in the presence of the pure antioestrogens, ZM 182780 and RU 58668 (Van de Velde et al. 1994), they are killed. During studies to determine the role of other steroid-activated pathways in this response, we have observed that death induced by antioestrogens was blocked by the glucocorticoid, Dex.
These observations contribute to the growing controversy concerning the role of glucocorticoids in cell survival.

A classical model of apoptosis is the glucocorticoidinduced death of thymocytes (Schwartzman \& Cidlowski 1994). Further support for a pro-death role of glucocorticoids comes from the studies on Alzheimer's disease. Alzheimer's disease is associated with aging and hippocampal cell death and there is an age-related increase in the activity of the hypothalamus-pituitary axis (Behl et al. 1997). These observations have prompted studies showing that Dex enhances oxidant-induced hippocampal cell death (Behl et al. 1997, Reagan \& McEwen 1997). In addition to this, studies have demonstrated that glucocorticoids enhance neuronal ischaemic necrosis (Sapolsky \& Pulsinelli 1995). Although necrosis can be due to physical cell injury, in the majority of cases it is due to severely compromised cell energetics (Eguchi et al. 1997, 1999). During ischaemic injury, mitochondrial function is restricted by low $\mathrm{O}_{2}$ concentrations, rendering cells dependent on glycolytic function (Maxwell \& Lip 1997). Glucocorticoid-enhanced necrosis under these circumstances may be due to the observed down-regulation of glucose uptake by these hormones (Rist \& Naftalin 1991). Contrary to these reports, it has been demonstrated that Dex prevents cell death in a neonatal rat model of hypoxic-ischaemic encephalopathy (Ekert et al. 1997). Here it was reported that cell death was by apoptosis. Similarly, there are other reports to indicate that liver cell, neutrophil, pancreatic acinar cell and breast cell apoptosis is blocked by glucocorticoids (Feng et al. 1995, Harris et al. 1995, Liles et al. 1995, Iida et al. 1998). From these conflicting studies it would appear that the effect of glucocorticoid exposure is very much cell-type dependent. Our study now shows that for a pituitary tumour cell line, cell death in response to oxidants is also blocked by Dex.

Our earlier reports on these pituitary tumour cells maintained that cell death in response to the antioestrogen ZM 182780 and to exogenous oxidants had more of the characteristic of apoptosis than necrosis (Newton 1995, Newton et al. 1999). Having performed more extensive studies on these cells, we now believe that cell death induced by antioestrogens and oxidants is more characteristic of necrosis. The confusion with regard to assigning the correct mode of cell death has arisen for several reasons. The first of these is that antioestrogens cause considerable cell shrinkage prior to rapid death - this is a characteristic of apoptosis in a number of systems (Schwartzman \& Cidlowski 1993). We have now performed experiments showing that a reduction in cell volume in response to ZM 182780 is not always followed by cell death (data not shown). Secondly, using an ELISA assay that fails to detect necrosis in endothelial cells (Newton et al. 1999), marked DNA fragmentation was detected in response to antioestrogen and oxidants. The third factor that has given rise to this confusion is the unusual dose-response to $\mathrm{H}_{2} \mathrm{O}_{2}$. In 
the majority of cell systems, low oxidant doses induce apoptosis and high doses induce necrosis. For $\mathrm{GH}_{3}$ cells, we have observed that low doses of $\mathrm{H}_{2} \mathrm{O}_{2}$ induce rapid death whilst death at higher doses is delayed for several hours.

A re-evaluation of the characteristics of oxidant-induced cell death, as presented here, has provided the findings that the loss of $\Delta \Psi_{\mathrm{m}}$, a characteristic response of early apoptosis in a number of systems, cannot be disassociated from a loss of cell membrane integrity (see Figs 5 and 6). In practical terms, at every time-point of $\Delta \Psi_{\mathrm{m}}$ measurement with the cationic fluorochrome, $\mathrm{DiOC}_{6}$, PI uptake correlates with the fall in $\Delta \Psi_{\mathrm{m}}$. This strongly suggests that a catastrophic loss of membrane function has occurred resulting in the loss of mitochondrial function. Data presented in Fig. 7 showing that at high $\mathrm{H}_{2} \mathrm{O}_{2}$ doses, cell membrane integrity is intact when the $\Delta \Psi_{\mathrm{m}}$ has collapsed indicate that cell membrane function is not lost as a secondary response to a collapse of mitochondrial function and ATP generation. Indeed data presented in Fig. 8 indicate that the absolute level of ATP, measured in the whole population of cells under treatment, does not determine the viability of the cells. Therefore, high doses of $\mathrm{H}_{2} \mathrm{O}_{2}$ induce a large fall (95\%) in ATP concentrations and yet cell membrane integrity is maintained for several hours. In contrast, at the lower doses of $\mathrm{H}_{2} \mathrm{O}_{2}$, loss of cell membrane function is apparent when ATP concentrations have only fallen to around $30-40 \%$ of control values. Our observations of a rapid uptake of PI indicate a catastrophic loss of membrane function for a proportion of the cell population. One of the possibilities we have considered is that such an effect was due to oxidation of membrane lipids. Although not shown, we have attempted to address this by determining glutathione (GSH) concentration with the fluorescent probe, Cell Tracker Green (Molecular Probes). In our earlier publication we have shown that GSH is a major antioxidant in these cells (Newton et al. 1999). In the presence of GSH and the enzyme glutathione-S-transferase, Cell Tracker Green is converted to a green fluorescent compound. Using this method, we have been unable to detect a loss of GSH in response to $\mathrm{H}_{2} \mathrm{O}_{2}$ until the time at which cell membrane rupture has occurred. For this reason, we believe that the loss of membrane integrity has, paradoxically, more to do with the energetic status of the cells than the antioxidant status. In particular, we propose that high oxidant doses induce a 'shut-down' of cellular activities, sparing the remaining ATP for the maintenance of cell membrane function. At the lower doses of $\mathrm{H}_{2} \mathrm{O}_{2}$, ATPconsuming cellular processes will not be as markedly inhibited and therefore the demand on the diminishing pool of ATP will be higher. As the cell energetics continue to fall in response to oxidative damage, a crisis point will be reached at which demand outstrips supply, leading to a rapid and catastrophic loss of plasma membrane $\mathrm{Na}^{+} / \mathrm{K}^{+}-$ ATPase and membrane integrity. Our inability to measure this rapid fall in ATP concentrations on an individual cell basis before membrane integrity is lost is due to the current lack of suitable methodology.

With regard to the mechanism by which Dex blocks antioestrogen- and oxidant-induced cell death, we have had to first identify a mechanism by which oxidants induce cell death. Given our observations in Fig. 9 concerning membrane blebbing, in the light of studies indicating that glycolysis drives the cytoskeletal changes that result in blebbing, we have tested the relative role of glycolysis and mitochondria in the response to $\mathrm{H}_{2} \mathrm{O}_{2}$. Data presented in Fig. 10 have shown that removal of glucose markedly enhances oxidant-induced cell death whilst, paradoxically, lowering mitochondrial function is protective. Previous studies by Sahlin (1995) have demonstrated that a key enzyme of glycolysis, GAPDH, is highly regulated by oestrogens and by Dex. In addition, studies have shown that GAPDH is a major target for oxidative damage due to the presence of a critical thiol group (Baker et al. 1989). Our data presented in Table 1 show that whilst enzyme activity is not markedly altered in response to $\mathrm{ZM} 182780$ and Dex alone, in the presence of $\mathrm{H}_{2} \mathrm{O}_{2}$, antioestrogen pretreatment leads to an enhanced reduction of GAPDH activity following $\mathrm{H}_{2} \mathrm{O}_{2}$ exposure, and this effect is blocked by Dex. These data strongly indicate that one of the mechanisms by which Dex is able to block antioestrogen-enhanced, oxidant-induced cell death is that the steroid stabilises glycolytic function. In contrast to these results on glycolytic function, the results presented in Fig. 10 have provided the intriguing possibility that mitochondrial function, in part, drives the death process. Here it was shown that the two agents that lower mitochondrial activity reduce death in the presence of the low doses of $\mathrm{H}_{2} \mathrm{O}_{2}$.

These data presented in the current report support the previous studies on $\mathrm{GH}_{3}$ cells that antioestrogens enhance sensitivity to the toxic effect of oxidants. We now show that this effect is blocked by the glucocorticoid, Dex, possibly due to the role that the Dex-activated GR has to stimulate glycolysis - a pathway that we show here to be fundamental in the response of these cells to oxidants. These finding therefore contribute to the growing body of data to suggest that, for certain cell types, glucocorticoids decrease susceptibility to toxic insults. Cellular energetics have been shown to be fundamental with regard to how a cell responds to a particular toxic agents. Apoptosis is an energetic process and stimuli that normally induce apoptosis have been shown to induce necrosis when cellular ATP levels are reduced (Eguchi et al. 1997, 1999). By blocking necrosis, one might have expected that Dex would allow apoptosis to occur. The failure to observed apoptosis is not due an inability of $\mathrm{GH}_{3}$ cells to undergo apoptosis, as we have recently observed this mode of death in response to the calmodulin inhibitor, calmidzolium chloride (Newton et al. 2000). Our most recent unpublished observations on these cells may provide the explanation for this. In response to the topoisomerase 
inhibitor, camphothecin, $\mathrm{GH}_{3}$ cells undergo nuclear fragmentation characteristic of apoptosis and this is blocked by Dex. Therefore, our studies concur with those of others showing that glucocorticoids block both necrotic and apoptotic cell death. Although we have provided some evidence to support a mechanism by which necrosis is blocked, studies are required to determine at which step in the apoptotic pathway Dex is able to block apoptosis.

\section{Acknowledgements}

The authors would like to thank Yorkshire Cancer Research for their support during this study and Andrew Howe and Hollie Jones for their help in preparation of this document.

\section{References}

Baker MS, Feigan J \& Lowther DA 1989 The mechanism of chondrocyte hydrogen peroxide damage depletion of intracellular ATP due to suppression of glycolysis caused by oxidation of glyceraldehyde-3-phosphate dehydrogenase. Journal of Rheumatology 16 7-14.

Behl C, Lezoualc'h F, Trapp T, Widmenn M, Skutella T \& Holsboer F 1997 Glucocorticoids enhance oxidative stress-induced cell death of hippocampal neurones in vitro. Endocrinology 138 101-106.

Bigsby RM \& Young PCM 1993 Progesterone and dexamethasone inhibition of uterine epithelial cell proliferation studies with antiprogesterone compounds in the neonatal mouse. Journal of Steroid Biochemistry and Molecular Biology 46 253-257.

Bunone G, Briand P-A, Miksicek RJ \& Picard D 1996 Activation of the unliganded estrogen receptor by EGF involves the MAP kinase pathway and direct phosphorylation. EMBO Journal 156 2174-2183.

Coulter CV, Kelso GF, Lin TK, Smith RAJ \& Murphy MP 2000 Mitochondrially targeted antioxidants and thiol reagents. Free Radical Biology and Medicine 28 1547-1554.

Decaudin D, Geley S, Hirsch T, Castedo M, Marchetti P, Macho A, Kofler R \& Kroemer G 1997 Bcl-2 and Bcl-X $\mathrm{L}_{\mathrm{L}}$ antagonize mitochondrial dysfunction preceding nuclear apoptosis induced by chemotherapeutic agents. Cancer Research 57 62-67.

Eguchi Y, Shimizu S \& Tsujimoto Y 1997 Intracellular ATP levels determine the fate by apoptosis or necrosis. Cancer Research $\mathbf{5 7}$ 1835-1840.

Eguchi Y, Srinivasan A, Tomaselli KJ, Shigeomi S \& Tsujimoto Y 1999 ATP-dependent steps in apoptotic signal transduction. Cancer Research 59 2174-2181.

Ekert P, MacLusky N, Luo P, Lehotay DC, Smith B, Post M \& Tanswell AK 1997 Dexamethasone prevents apoptosis in a neonatal rat model of hypoxic-ischemic encephalopathy (HIE) by a reactive oxygen species-independent mechanism. Brain Research 747 9-17.

Feng Z, Marti A, Jehn B, Altermatt HJ, Chicaiza G \& Jaggi R 1995 Glucocorticoid and progesterone inhibit involution and programmed cell death in the mouse mammary gland. Journal of Cell Biology 131 1095-1103.

Friend KE, Chiou YK, Lopes MBS, Laws ER, Hughes KM \& Shupnik MA 1994 Estrogen receptor expression in human pituitary correlation with immunohistochemistry in normal tissue and immunohistochemistry and morphology in macroadenomas. Journal of Clinical Endocrinology and Metabolism 78 1497-1504.

Glass-Marmor L \& Beitner R 1997 Detachment of glycolytic enzymes from cytoskeleton of melanoma cells induced by calmodulin agonists. European Journal of Pharmacology 328 241-248.
Halder J, Ray M \& Ray S 1993 Inhibition of glycolysis and mitochondrial respiration of ehrlich ascites carcinoma cells by methylglyoxal. International Journal of Cancer 54 443-449.

Harris RA, Hiles ID, Page MJ \& O'Hare MJ 1995 The induction of apoptosis in human mammary luminal epithelial cells by expression of activated c-neu and its abrogation by glucocorticoids. British Journal of Cancer 72 386-392.

Haug E \& Gautvik KM 1976 Effects of sex steroids on prolactin secreting rat pituitary cells in culture. Endocrinology 99 1482-1487.

Hurd C \& Moudgil VK 1998 Steroid hormone receptor families. In Handbook of Physiology, vol. 1, pp 383-411. Ed. M Conn. Oxford, UK: Oxford University Press.

Iida N, Sugiyama A, Myoubudani H, Inoue K, Sugamata M, Ihara T, Ueno Y \& Tashiro F 1998 Suppression of arachidonic acid cascade-mediated apoptosis in aflatoxin $\mathrm{B}_{1}$-induced rat hepatoma cells by glucocorticoids. Carcinogenesis 19 1191-1202.

Katzenellenbogen BS, Bhakoo HS, Ferguson ER, Lan NC, Tatee T, Tsai TL \& Katzenellenbogen JA 1979 Estrogen and antiestrogen action in reproductive tissues and tumours. Recent Progress in Hormone Research 35 259-300.

Keller JN, Guo Q, Holtsberg FW, Bruce-Keller AJ \& Mattson MP 1998 Increased sensitivity to mitochondrial toxin-induced apoptosis in neural cells expressing mutant presenilin-1 linked to perturbed calcium homeostasis and enhanced oxyradical production. Journal of Neuroscience 18 4439-4450.

Liles WC, Dale DC \& Klebanoff SJ 1995 Glucocorticoids inhibit apoptosis of human neutrophils. Blood 86 3181-3188.

Maxwell SRJ \& Lip GYH 1997 Reperfusion injury: a review of the pathophysiology, clinical manifestations and therapeutic options. International Journal of Cardiology 58 95-117.

Morita S, Matsuo K, Tsuruta M, Leng S, Yamashita S, Izumi M \& Nagataki S 1990 Stimulatory effect of retinoic acid on GH gene expression: the interaction of retinoic acid and tri-iodothyronine in rat pituitary cells. Journal of Endocrinology 125 251-256.

Newton CJ 1995 Estrogen receptor blockade by the pure antiestrogen, ZM 182780, induces death of pituitary tumour cells. Journal of Steroid Biochemistry and Molecular Biology 55 327-336.

Newton CJ, Arzt E \& Stalla GK 1994a Involvement of the estrogen receptor in the growth response of pituitary tumour cells to interleukin-2. Biochemical and Biophysical Research Communications 205 1930-1937.

Newton CJ, Buric R, Trapp T, Brockmeier S, Pagotto U \& Stalla GK $1994 b$ The unliganded estrogen receptor (ER) transduces growth factor signals. Journal of Steroid Biochemistry and Molecular Biology 48 481-486.

Newton CJ, Trapp T, Pagotto U, Renner U, Buric R \& Stalla GK $1994 c$ The oestrogen receptor modulates growth of pituitary tumour cells in the absence of exogenous oestrogen. Journal of Molecular Endocrinology 12 303-312.

Newton CJ, Drummond N, Burgoyne CH, Speirs V, Stalla GK \& Atkin SL 1999 Functional inactivation of the oestrogen receptor by the antiestrogen, ZM 182780, sensitises tumour cells to reactive oxygen species. Journal of Endocrinology 161 199-210.

Newton CJ, Eycott K, Green V \& Atkin SL 2000 Response of estrogen receptor-containing tumour cells to pure antiestrogens and the calmodulin inhibitor, calmidzolium chloride. Journal of Steroid Biochemistry and Molecular Biology 73 29-38.

Perrone MH, Greer TL \& Hinkle PA 1980 Relationship between thyroid hormone and glucocorticoid effects in $\mathrm{GH}_{3}$ pituitary cells Endocrinology 106 600-605.

Reagan LP \& McEwen BS 1997 Controversies surrounding glucocorticoid-mediated cell death in the hippocampus. Journal of Chemical Neuroanatomy 13 149-167.

Rist RJ \& Naftalin RJ 1991 Dexamethasone inhibits the hexose monophosphate shunt in activated rat peritoneal macrophages by reducing hexokinase-mediated sugar uptake. Biochemical Journal 278 $129-135$. 
Sahlin L 1995 Dexamethasone attenuates the estradiol-induced increase of IGF-I mRNA in the rat uterus. Journal of Steroid Biochemistry and Molecular Biology 55 9-15.

Sapolsky RM \& Pulsinelli WA 1995 Glucocorticoids potentiate ischemic injury to neurones: therapeutic implications. Science $\mathbf{2 2 9}$ 1397-1400.

Scheek RM \& Slater EC 1982 Glyceradehyde-3-phosphate dehydrogenase from rabbit muscle. Methods in Enzymology 89 305-309.

Schwartzman RA \& Cidlowski JA 1993 Apoptosis. The biochemistry and molecular biology of programmed cell death. Endocrine Reviews 14 133-151.

Schwartzman RA \& Cidlowski JA 1994 Glucocorticoid-induced apoptosis of lymphoid cells. International Archives of Allergy and Immunology 105 347-354.

Sorrentino JM, Kirkland WL \& Sirbasku DA 1976 Control of cell growth. I. Estrogen independent growth in vivo of a rat pituitary tumor cell line. Journal of the National Cancer Institute 56 1149-1154.

Tashjian AH, Yasumura L, Levine L, Sato GH \& Parker ML 1968 Establishment of clonal strains of rat pituitary tumor cells that secrete growth hormone. Endocrinology 82 342-352.

Van de Velde P, Nique F, Bouchoux F, Bremaud J, Hameau MC, Lucas D, Moratille C, Viet S, Philibert D \& Teutsch G 1994
RU 58668, a new pure antiestrogen inducing a regression of human mammary carcinoma implanted in nude mice. Journal of Steroid Biochemistry and Molecular Biology 48 187-196.

Wakeling AE \& Bowler J 1991 A potent specific pure antiestrogen with clinical potential. Cancer Research 51 3867-3873.

Wiklund J, Wertz N \& Gorski J 1981 A comparison of estrogen effects on uterine and pituitary growth and prolactin synthesis in F344 and Holtzman rats. Endocrinology 109 1700-1707.

Zhou-Li F, Joly-Pharaboz MO, Bouillard B, Albaladejo V, Nicolas B \& Andre J 1991 Multihormonal contrology of cell proliferation opposite effects of two stimulators $(17 \beta$ estradiol and L-triiodothyronine and one inhibitor (dexamethasone on $\mathrm{F}_{4} \mathrm{Z}_{2}$ pituitary tumor cells. Endocrinology 128 2761-2768.

Zhou-Li F, Albaladejo V, Joly-Pharaboz MO, Nicolas B \& Andre J 1992 Antiestrogens prevent the stimulatory effects of L-triiodothyronine on cell proliferation. Endocrinology 130 $1145-1152$.

Received in final form 22 December 2000 Accepted 9 January 2001 